\title{
The Challenge of the College Computer Basic Education in Big Data Environment
}

\author{
Jinlan Guo \\ Shanghai University of Political Science and Law, China
}

Keywords: Big data, Regular institutions, Computer, Basic education

\begin{abstract}
With the advent of information age, notebook computers, mobile phones, the function of mobile terminals gradually diversified, especially WeChat, Moments, Weibo and other social networks, in this way, the ordinary university students' daily life behavior produces a large amount of data information, thus, the ordinary university teachers' decision making more and more depends on data analysis. Information data are affecting the development of teaching in common colleges and universities, education, education management, the mode of thinking, learning, behavior, teaching evaluation and so on are all affected by big data, so there is reason to believe that big data could be the revolution of basic computer education.
\end{abstract}

\section{Introduction}

With the development of information technology and computer popularization of computer has been widely used in various fields of society, social demand for college graduates of computer application ability more and more is also high. Premier Jiabao Wen in the fourth national conference on education also explicitly pointed out that, comprehensively promote quality education, is to deepen the reform of the curriculum and teaching, innovative teaching ideas, teaching contents, teaching methods, focus on improving the students' learning ability, practice ability, innovation ability, to realize the entire development of students. In science, technology and society into the information age, basic computer education in colleges and universities and puts forward the new requirements. The challenges of the information society is characterized by the challenge of "viability", for college students, good computer skills are far cannot meet the needs of society, "live" to in the information era, we must skillfully use computer technology, identification, processing, transfer and create information [1], it is more important in the information environment has the independent learning ability and innovation consciousness, all these need the joint efforts of teachers and students, eventually improve the information literacy, promote the comprehensive development of students' lifelong learning, such as the ancients said: "ma fu Li, not can hasten the Tao, do not state ". Since the $1990 \mathrm{~s}$, countries around the world are the education informationization as the promote education reform and development of all types and at all levels of major strategic measures, countries are invested billions, or even hundreds of billions of dollars of funds for education informationization construction of software and hardware infrastructure.

\section{The characteristics of big data}

Big data from literal meaning to understand is the large data sets. As one of the more abstract and new concept, there is no unity a precise definition. In a narrow sense, big data refers to the large amount of data, in which people can no longer in a short period of time for the data collecting, sorting, analysis, data sets, also is the literal meaning of the big data; Broadly speaking, the big data is dealing with large data sets of collecting, sorting, analysis, collection of a series of methods, means and tools [1].

Sum up big data has four characteristics, respectively is:

\subsection{The large amount of data}

Large data amount of data is huge, in the order of TB has not meet the needs of its data, but 
extended to PB and ZB, YB level.

\subsection{Diversification}

The structure of the data types from a single structure into a diversified type, including web pages, images, audio, video, geographic location, such as semi-structured or unstructured data.

\subsection{Data rapidness}

Data produced by the rhythm and hungry as a car fast rhythm of life, so you need efficient and timely monitoring, data processing method.

\section{The current problems existing in college basic computer education}

Along with the popularization of computers in schools and families, university computer basis education is out of the "zero", colleges and universities also opened accordingly "computer culture basis", "C language program design" and "VB language program design" and so on the foundation course, but the problem is obvious:

\subsection{The relatively lagging teaching content}

Because the computer technology and the development of information technology has a rapid speed, the ordinary university computer teaching content can not keep up with the development of computer technology and the update completely, so the teaching content lag phenomenon is widespread in our country ordinary university computer teaching work. For example, the application of image processing software is one of important teaching content in the ordinary university computer teaching. Adobe in July 2013 launched the latest version of Photoshop; this makes version PhotoshopCS6 AdopCS series in the last version [2]. However ordinary university computer teaching in Photoshop teaching is still AdopCS series as the main teaching content. In today's society computer technology represents the most advanced productive forces, and play an important role in the development of the society, so the learners should also pursuit of innovation, learning content, and teaching content that exists in ordinary colleges and universities is not only difficult to effectively arouse the enthusiasm of students in learning in computer teaching, and also difficult to realize the students' ability of practical application of computer technology. And teachers in order to make solution to the problem, can only through targeted teaching in the teaching process, is still in Photoshop image processing software, for example, teachers need in the computer room and install the latest version of Photoshop software, and based on the teaching content is guides the student to study, to make students understand the latest version of the latest functions.

\subsection{The lack of qualified teachers}

Ordinary university enrollment expansion to promote the realization of the popularization of higher education, but also to college education, including teaching resources, the allocation of resources put forward the severe challenge, especially for the newly built undergraduate course colleges and universities, by historical background, geographical location, basic conditions and the influence of famous degree, in computer teaching, the teachers troop construction is very difficult [2]. And in order to realize the regular institutions of higher learning, including newly built undergraduate course colleges and universities, educational level, education level and teaching quality of computer, build a professional, high-quality teaching staff is the key. Current our country ordinary university computer teaching in the teaching staff construction problems facing the mainly reflected in the following aspects: high proportion of the teachers and students. With a high title and highly educated teachers structure is relatively low. Scientific research level and teaching level is not ideal in general; High quality teachers' introduction is difficult. From as main force of ordinary university computer teaching young teachers teaching features, although young teachers with high academic level, but is generally a broad ideal, research, writing, and the pursuit of results is much higher than in the enthusiasm of the computer to make study and practice of teaching reform, some young teachers think computer basis teaching is difficult to show their talents, think its business development is 
restricted. In addition, some young teachers is not graduated from normal, so they used teaching method in computer teaching lacks systemic lack of flexibility and their teaching ability, this led to their teaching effect is not ideal [2]. With average college enrollment expansion, many young teachers often directly involved in the computer classroom teaching job after the job, the rush of phenomenon leads to the teachers to complete the change of role and meet the requirements for roles, and to make them at the bear heavy teaching tasks at the same time do not have much energy to carry out teaching reflection and summary.

\subsection{The relatively backward teaching mode}

The development of computer technology to make our country ordinary university computer teaching in the update teaching content and increase year by year, and the pattern of computer teaching is given priority to with blackboard and chalk has the more obvious volatility, because in this kind of teaching method, in the face of heavy computer teaching tasks, teaching content can't intuitive presented to students, with poor visibility not only affects the teacher explained the accuracy, and increase the difficulty of the student's understanding of computer knowledge. From the point of theory teaching, the teaching of computer theory for normal university simply copy text paragraphs describes the phenomenon still exists objectively, in this case, the lesson plan planning of unity and advancing with the times, and lack of creative teaching process, so students feel theory class teaching is too dull and boring and hard to improve the knowledge of computer theory study interest [1]. From the point of practical teaching, many ordinary colleges and universities in computer practice teaching for the students to carry out free computer activities, in this process because of the lack of task driven and learning objectives, basic knowledge of the students is difficult to effectively internalized in the practice teaching, and students' skills are hard to get exercise.

\section{To create a good learning environment with big data technology}

In the era of big data, information accesses directly affect industrial school student mastery of knowledge. How can keep pace with The Times, adapt to the era of big data, the effective use of big data technology and applied to the computer application foundation course, cultivating students' innovation ability, education workers are facing new challenges and opportunities.

\subsection{The teaching idea transformation}

Along with the progress and development of network technology and multimedia technology, big data, large-scale online education platform will bring the teaching idea of school teachers in common colleges and universities deeply influenced, the ordinary university school students access to the knowledge will no longer be limited to the classroom.

"Flip" classroom teaching organization form is in present online learning prevailing at the time of formation, in such form under the effect of the traditional teaching mode is the assistance [3]. And limited time space, step-by-step compared to the traditional classroom teaching mode, which will gradually change the previous classroom teaching model will be more suitable for computer application basis of ordinary college students, more can provide funding for learning space, the ordinary university students can according to their own characteristics, the study on my own time and place, effectively reduce the disadvantages brought by the ordinary university classroom teaching and learning process can avoid to produce fatigue, improve the learning efficiency.

Teachers in common colleges and universities can dig through the students learning behavior mode, data statistics, induction, analysis, to study law, and then determine what knowledge points need to be emphasized, and differential treatment in education, according to their aptitude, targeted to carry out teaching activities, review guide [3]. Through a lot of teaching data, the ordinary university curriculum resources of repeated testing and improvements, to further improve the computer application foundation course online teaching resources of high quality.

\subsection{The innovation of the teaching content}

Big data era education activities, the knowledge is vast, technical school life knowledge not only 
from teachers that get, there are more and more knowledge acquired from "network", in the acquisition of knowledge at the same time, industrial school student learning behavior and process were also recorded [3]. Therefore, teachers should according to the characteristics of the various professional to adjust the teaching content, on the basis of ordinary university interdisciplinary training objectives, setting up reasonable teaching basic knowledge of computer application course, the big data knowledge, computer application knowledge and relevant knowledge into the teaching of the related problems, application of teaching to carry on the reasonable configuration, classification, such as applying computer basic knowledge and professional skills, according to the professional characteristics, establishing open and personalized training scheme, not only can stimulate the enthusiasm of industrial school student learn professional skills, but also guide the industrial school student form use computers to solve problems of professional thinking mode, to adapt to the big data environment is a positive role in guiding the teaching work.

\subsection{The innovation of the teaching mode and teaching method}

In the lead of big data of innovation education is not merely only pay attention to the results of operations, it emphasizes the discovery of knowledge, therefore need to reform the teaching mode and teaching methods, such as effective use of reverse in such advanced means in teaching classroom, micro courses [4].

Micro class as a kind of new teaching concept and mode, has been in various regions of China is actively promote, make a lot of sharing high-quality resources has become a reality. Go the way of a good soldier is micro class, namely the elaborating management teaching mode, students in the learning process in case of confusion, can be suspended, replay and convenient personal achieve learning goals.

In this mode, the course design is different. Industrial school student can realize autonomous learning through micro class first, if really can't solve the problems, recorded please provide guidance to teachers, mainly through the experiment, discussion in class, homework and other activities to digest what they have learned knowledge.

During fully understand the lesson, on the basis of large data, to be effective for computer application basis classroom innovative teaching practice, to realize the change of cultivation to the innovation ability by knowledge.

\subsection{The evaluation system of innovation}

Evaluation of teaching both sides to seventy percent "baton" function is the power of innovation ability training [4]. Apply based on large of data mining algorithm in computer application foundation course teaching evaluation work, find out the teaching effect, the application of computer technology in teaching, communication, interaction between teachers and students of the relationship between the factors such as, which brings to the teaching management more scientific decision information, to make teachers can be more effective to carry out the teaching work, improve the quality of teaching.

\subsection{To strengthen the construction of teaching staff}

Teachers in common colleges and universities need to further update teaching theory, teaching mode innovation, achieve the sustainable development of teaching, scientific research and learning [5]. Combining teaching with scientific research, promote each other, constantly improve, to adapt to the ordinary university computer teaching reform and development needs, is to the ordinary university teachers to the ability of using big data analysis, the new requirements.

\section{Big data for the opportunities brought about by the basic computer application course in common colleges and universities}

Explore the law of development of education era of big data, to find the direction of the future education, thus in the teaching activities of the computer basic course in common colleges and universities into big data base, in order to bring real change to the teaching, let every industrial school 
student to suit his own steps and methods to learning, improve their professional quality and innovative ability.

\subsection{The analysis of the effect of effective teaching evaluation}

From the point of view of teachers, into the era of big data, can the past through the analysis of the technology of data storage teaching problems, solutions, and to recommend lace teaching problems in need of solution, namely the realization of teaching on the basis of data analysis, problem solving, adjust the teaching method and teaching strategies, so that they can make the teaching effect of continuous optimization [5].

From the point of view of students, from you to rely on the teachers' limited face turned to their own learning process for data analysis. In the era of big data, the teacher is entirely possible for each student's learning data were analyzed, and the implementation of adaptive character teaching, the students throughout the learning process of digitization, and connecting with the great data test and analysis system, including teaching materials, learning activities and learning interest bias [6]. Through data analysis, such as through to the wrong topic analysis found that students know what knowledge has a problem, and corresponding remedial counseling for students vary from person to person, such as automatic push corresponding knowledge on issues related to knowledge and testing, etc., thus to reasonable arrangement of teaching steps, assist in teaching reform. Big data automatically discover students' learning interest, learning habits and achievement evaluation is possible.

\subsection{To enhance the level of college teaching and meet the need of social development}

Under the background of big data, and through the big data can be applied to the analysis of the teaching guide students to form the application of computer to solve the problems of the professional logistic thinking mode, cultivate students' innovative thinking and the actual operation ability, and to solve the problem truly to students' autonomous learning as the main body, so as to better meet the needs of jobs [5].

\subsection{To strengthen the interactive and real-time teaching}

Introduction of the technique of big data to computer application basic course teaching platform, can be combined with face-to-face teaching and learning online, online visible in extracurricular, micro class resources such as prepare, review the course content, and then discuss the content of the learned in class [6]. Through various forms of interaction between teachers and students, expands the learning and communication channels between teachers and students, strengthen the study effect, virtually improve the quality of the course teaching, is helpful to find type and collaborative teaching, stimulate students' learning enthusiasm, cultivate the students' information acquisition ability and team cooperation ability, students can deepen understanding and using of knowledge of computer science and really use it.

Under the background in the era of big data, computer application basic course teaching reform in common colleges and universities is not achieved overnight, but it is a difficult and complex subject, need a long process [6]. To keep up with the development of big data technology, introduce advanced thought, method and theory, is constantly trying to developing better and better, more effective to the cultivation of the students practice ability and innovation ability.

\section{Summary}

Institutions of higher learning basic computer education to enter into a new stage, will have new breakthrough and improve. Which requires the computer basic education workers comprehensive in-depth summary for many years of experience, carefully study the mission and requirements of the new situation make a clear definition of the guiding ideology of computer based education, vigorously promote effective experience. The basic computer education of colleges and universities promote to a new step. 


\section{References}

[1] R. Y. Wang, Reform and practice of basic computer course teaching, Journal of Heilongjiang Institute of Education, 2013, vol. 2, pp. 13-15.

[2] F. K. Zhao, Learning model based on the innovation education under the network environment, Journal of central China normal university, 2004, vol. 3, pp. 34-37.

[3] Y. L. Chen, The information education and the cultivation of innovative talents, Audio-visual education research, 2003, vol. 12, pp. 9-11.

[4] W. F. Li, Long-term development trend of information science and technology and China's strategic orientation, Chinese science information science, 2010, vol. 9, pp. 16 to 18.

[5] X. Y. Gao, Informationization of college basic computer course teaching design and practice research, Anhui normal university, 2012, vol. 5, pp. 43-47.

[6] M. H. Cheng, Pattern research of University computer foundation course exploratory teaching, Northeast normal university, 2011, vol. 8, pp. 8-10. 